\title{
Creative Approaches to the Creation of Contemporary Art Objects and Features of their Legal Protection
}

\author{
Nataliia M. Myronenko ${ }^{1, *}$, Olena O. Shtefan ${ }^{2}$, Yuliia O. Kedia ${ }^{3}$, Olha B. Derkach ${ }^{3}$ and \\ Kateryna O. Semeniuk ${ }^{3}$
}

${ }^{1}$ Department of Directorate, Scientific Research Institute of Intellectual Property, National Academy of Legal Sciences of Ukraine, Kyiv, Ukraine

${ }^{2}$ Department of Jurisdictional Forms of Legal Protection of Privacy, Judicial and Judicial Entities, Academician F.H. Burchak Scientific and Research Institute of Private Law and Entrepreneurship of the National Academy of Legal Sciences of Ukraine, Kyiv, Ukraine

${ }^{3}$ Postgraduate Department, Scientific Research Institute of Intellectual Property, National Academy of Legal Sciences of Ukraine, Kyiv, Ukraine

\begin{abstract}
This study is devoted to the analysis of the current state of legislation of Ukraine and EU countries on copyright protection of works with an unstable form of expression, as well as to determine the features of the legal protection of such objects. The purpose of the article was to explore the existing possibilities in the law of Ukraine and the law of the EU countries for the protection of works with an unstable form of their expression. The article, based on the analysis of international legal acts and national legislation, highlights the elements of protection of works. A significant place in work is devoted to the analysis of theoretical, legislative approaches to the definition of "creativity", "originality", "novelty". It is stated that there is no single waste to the definition of these concepts in the literature and not regulated in the legislation in the field of copyright. A comparative legal analysis of the case-law of the United Kingdom and the United States on the provision of legal protection to works with an unstable form. It is concluded that the normative definition of "creative work", which is associated exclusively with works of cultural value, is not acceptable for copyright. The article analyses the judicial practice of Ukraine, which has developed in the definition of creative work and illustrates its ambiguity. It is concluded that judges, considering such cases, try to find some stable elements that are inherent in works with an unstable form of expression.
\end{abstract}

Keywords: Intellectual property law, object of intellectual property law, subjects of intellectual property law.

\section{INTRODUCTION}

Creativity is an integral part of human nature. Due to their will, produced by the intellect, most people express themselves in the creation of objects of intellectual property rights. This creative intellectual activity can be related to a person's professional activity or be a hobby. The creative activity of people has no limits and is inherent only in human. Since ancient times, the ancient philosophers Democritus, Epicurus, Plato, Aristotle, and Socrates paid attention to the disclosure of the essence of creative freedom through the analysis of such categories as "creativity", "freedom", "truth". Later, the medieval philosophers Spinoza, Kant, Hegel, and F. Aquinas, as well as modern-day philosophers T. Hobbes, S.-L. Montesquieu, J.-P. Sartre, A. Camus, E. Fromm took over their baton in the knowledge of creative freedom. In their works, these philosophers laid the foundation for understanding the freedom of creativity, which later allowed the humanities to find their own ways to

*Address correspondence to this author at the Academician F.H. Burchak Scientific and Research Institute of Private Law and Entrepreneurship of the National Academy of Legal Sciences of Ukraine, Kyiv, Ukraine; Tel: (044) 286 35 98; E-mail: prof.myronenko@uohk.com.cn establish the true meaning of the phenomenon of "creative freedom". Since the 19th century, many psychologists have tried to reveal the meaning of this phenomenon in their works. Freedom of creativity, and above all artistic creativity, as a principle of law has been recognised and enshrined at the international level in such international legal acts as the Article 27 (1) of the Universal Declaration of Human Rights (1948), the International Covenant on Civil and the Article 19 (2) of Political Rights (1966), the Article 13 (1) of the American Convention on Human Rights (1969), and the Article 10 of the Convention for the Protection of Human Rights and Fundamental Freedoms (1950).

Despite the fact that the Convention for the Protection of Human Rights and Fundamental Freedoms in Art. 10 does not directly enshrine the principle of freedom of creativity, but concerns freedom of expression, the European Court of Human Rights in its numerous judgments (for example, the case of Müller and others v. Switzerland, the case of Casado Coca v. Spain, the case of Alinak v. Turkey, etc.) substantiated the necessity to extend conventional protection to freedom of creativity. Freedom of expression is also mentioned in paragraph 3 of 
Directive 2001/29/EC on the harmonisation of certain aspects of copyright and related rights in the information society (the European Parliament and of the Council of May 22 2001). The principle of freedom of creativity was declared in the Constitution of Ukraine (Article 54) (Constitution of Ukraine 1996), as well as in the Constitutions of a number of European states: the Article 33 of the Constitution of the Italian Republic (1947), the Basic Law of the Federal Republic of Germany (1949), the Article 37 of the Constitution of the Portuguese Republic (1976), the Article 20 of the Constitution of the Kingdom of Spain (1978) and others.

People who are engaged in creative intellectual activity and just creative individuals, realising their ideas, are looking for different ways to implement them. The expansion of ways to implement creative ideas on the one hand due to the opportunities that arise in connection with the development of science and technology, and on the other - the desire of an individual to create an original and unique result, to achieve its efforts. Today, such methods have been invented to create objects of intellectual property rights, and especially objects of copyright, and materials are used that give such objects a property that is characterised by an unstable form. Therefore, both theoretical and practical questions arise as to whether such objects can acquire legal protection and copyright protection.

The methodology of this research is characterised by the use of general scientific and special legal research methods, including: analysis and synthesis, complex, systemic, comparative-legal, formal-legal, formal-logical, abstraction and generalisation.

The purpose of the article is to explore the existing possibilities in the law of Ukraine and the law of the EU countries for the protection of works with an unstable form of their expression. The task is to determine the features of the legal protection of copyright objects with an unstable form of expression.

\section{CHARACTERISTICS OF THE CRITERIA OF PROTECTABILITY OF A WORK AS A RESULT OF CREATIVE INTELLECTUAL ACTIVITY}

Currently, artists embodying their creative ideas, are not limited to paints, ink, pencils, canvas, paper. Thus, back in 1969, a method was invented to paint with sand on glass and create a sand animation, which involves painting with sand on glass, located horizontally, which is backlit by both monochromatic colour and multi- coloured flashing lights that pass into each other streams of light. The American artist Scott Wade borrowed this idea from the form of expression of a creative idea but slightly changed the material carrier and the material itself with which he expresses his creative idea. He looks for suitable cars in parking lots and decorates their dirty glass with a rag and a stick with portraits, landscapes, still life, caricatures or just funny pictures (Scott Wade 2019). It should be noted that among the paintings of his own authorship, Scott Wade creates copies of "academic" paintings, such as the legendary Mona Lisa and reproductions of paintings by Cassius Marcellus Coolidge and others. Followers of the American artist who turn dirty cars into "masterpieces" are: Russian artist Sergei Ushakov, who uses dirty glass as a canvas (2015), Azerbaijani artist Rafael Veyisov, who is not limited to dirty glass cars but paints the whole car (Rafael Veyisov 2013).

Instead, the British Simon Beck, wearing snowshoes, creates unique paintings in the snow (Dafoe 2020). Unsurpassed paintings and drawings are created on the sand or on the foam of coffee and other food products, etc. Of course, the snow and ice sculptures cannot be ignored, which have recently gained popularity, even festivals and competitions, for example, in China since 1963 the Harbin International Festival of Snow and Ice Sculptures takes place (2020). The artists did not ignore such material for the realisation of their creative ideas as sand, from which they build fantastic cities and create unsurpassed sculptures. This type of art can compete in popularity with the creation of sculptures from ice and snow. This area of creativity is also developing and spreading through the organisation and holding of relevant competitions and festivals (Sand sculptures 2020).

All these different works are united by one common feature - an unstable form of expression: sand is removed from the glass - a picture is gone, the rain- a picture is gone, the snow has melted - a picture is gone, the food is eaten - a picture is gone, and so on. Thus, one of the main questions arises: is the implementation of the principle of creative freedom limited to the form of expression of works? In search of an answer to this question, first of all, it is advisable to turn to the historical origins of the emergence of criteria for the protection of works as objects of copyright.

The basis for determining the criteria of protection of works, which received its further development and implementation in regulations of the mid-20th century, was laid by the German philosopher I.G. Fichte, who 
substantiated the idea of a protected form and unprotected content (2006). The concept of I.G. Fichte was developed by another German philosopher of the 19th century J. Kohler, who in his works argued that not all works could receive legal protection from the state, but only those that are the result of creative work of an artist. In addition, work may contain both unprotected elements depicting objective reality, and protected, which embodies the individuality, identity, spiritual world of an artist. It was J. Kohler who first linked the originality of work with creativity, defining it as an element of creativity (1949). The doctrine of the relationship between form and content of works, developed by German philosophers, became the basis for the creation of an appropriate concept in the doctrine of copyright. Such legal scholars as Kashanin, Matveev, Rachum-Twaig, de Baranda, Birštonas, substantiated an objective approach to the definition of creativity through the signs of novelty, uniqueness of the content of a work and the independence of an author $(2007 ; 2015 ; 2017 ; 2011 ; 2014)$.

These criteria for determining creativity are evaluative. There are no approaches to their definition in copyright doctrine. Today there is no answer to the question of how to measure novelty, provided that all works are based on the achievements of predecessors, how to measure the uniqueness of the content of a work and the independence of the authors, if there are many examples in history when a work of an artist was influenced by other artists. This will be especially noticeable when the subject and object of creative activity, means and material of expression of creative idea coincide when works are based on the same sources studied and used by their authors. Back in the 19th century the famous English writer Charles Colton noted that if a person steals from contemporaries, she will be accused of plagiarism, and if from the ancients will be praised for erudition (Colton 2004). Finally, how to measure creativity as an intellectual activity and who will take on such a burden.

In addition, the proposed criteria for the protection of work as a result of creative intellectual activity, directly related to the content of a work, which in fact has no practical significance, because regulations, enshrining the principles of protection of works do not proceed from the content. Thus, in accordance with Part 2 of Art. 2 of the Berne Convention for the Protection of Literary and Artistic Works, Part 3 of Art. 8 of the Law of Ukraine "On protection of copyright and related rights", legal protection applies only to the form of expression, and therefore the content of a work does not directly fall under the legal protection of copyright. Although the form is derived from the content, and the choice of a form by an author depends directly on an author's idea and its embodiment in the content. The transfer of the plot of work, first of all, is reflected in the content of a work. Instead, different works may have similar plots, themes, but embodied in different meanings due to the author's use of appropriate techniques that can most accurately convey the creative author's idea. If it is about literary works - a plot can be embodied, for example, in a work of different genres, set out in different authorial styles, through the use of certain literary techniques specific to this author, which makes his works recognisable by a reader. At the same time, if a work belongs to the fine arts, recognition of works by artists or sculptors, their attribution to certain areas in art, as a rule, is also carried out due to the peculiarities of the author's technique of creating a work. That is why modern researchers are less and less linking creativity with the content of a work, and define it in a subjective sense, through the originality of methods, tools, techniques used by an artist to express their creative ideas (Kashanin 2010).

This concept is also not indisputable. If to put it in the basis of determining the presence of creativity in works of art created on the sand, dirty cars, snow, coffee, etc., then, of course, artists used original tools and techniques to create their works. However, if this approach is applied to works of art created in "classical" ways using brushes, paints, canvases, etc., then such works of fine art will not be recognised as works, because they cannot be defined as the result of creative work, and therefore refer to those that may receive legal protection by copyright. But this contradicts reality and suggests that the proposed concept is not characterised by a universal methodology for determining the presence of creativity as a sign of the result.

It seems that creativity as an intellectual activity of human is a deeper and more extensive concept, the definition of which has not stopped for centuries, involving philosophers, psychologists, sociologists, lawyers and representatives of other fields of knowledge. This is explained by the fact that neither international legal acts nor national legislation contain a unified and universal definition of the concepts of "creativity" or "creative work". Consistent in the doctrine of copyright is the definition of creativity through intellectual activity, which results in the creation of qualitatively new, original, unique, authentic works of 
science, literature and art. Creative character is expressed in the novelty and originality of work both in form and content (Sudarikov 2009; Khokhlov 2008; Morgunova 2008).

It has been proven that the absence of novelty, uniqueness or originality in a work (due to the impossibility of defining them) does not give grounds to claim that it was not created as a result of creative intellectual work and is not subject to copyright.

\section{ANALYSIS OF INTERNATIONAL LEGAL ACTS AND LEGISLATION OF UKRAINE IN THE FIELD OF COPYRIGHT}

Ukrainian legislation in the field of copyright does not contain a normative definition of either "creativity", "originality" or "novelty". At the same time Art. 1 of the Law of Ukraine "On Professional Creative Workers and Creative Unions" establishes the definition of creative activity as an individual or collective creativity, the result of which is the creation or interpretation of works of cultural value (Sudarikov 2009). This definition does not solve the problem of terminological certainty, but on the contrary, is even more confusing, because the creative activity is defined through individual or collective creativity, while not defining them, and also indicates that as a result of such creativity should appear not just work or its interpretation but one that will have cultural value. Cultural values are always a reflection of a certain era, reflect a certain period of development of society, provide information on the features of artistic culture as a whole and its individual species.

It should be noted that in the legislation of Ukraine there is no definition of both "individual creativity" and "collective creativity". Instead, Art. 1 of the Law of Ukraine "On export, import and return of cultural values" enshrine the normative definition of cultural value as objects of material and spiritual culture that have artistic, historical, ethnographic and scientific significance and are subject to preservation, reproduction and protection in accordance with Ukrainian legislation. Also, this law provides an exclusive list of such objects, which include original works of art, graphics and sculptures, artistic compositions and montages of any materials, works of decorative and traditional folk art (Law of Ukraine No. 1068-XIV 1999). A similar definition of cultural values is contained in paragraph 18 of Art. 3 of the Customs Code of Ukraine (2012). At the international level, the consolidation of the category "cultural values" is contained in The Hague Convention of May 14, 1954 "On the Protection of Cultural Property in the Event of Armed Conflict". According to Art. 1 of the said Convention “... cultural values are considered irrespective of their origin and owner:

(a) valuables, movable or immovable, which are of great importance to the cultural heritage of each people, such as monuments of architecture, art or history, religious or secular, archaeological sites, architectural ensembles which are of historical or artistic interest as such, works of art, manuscripts, books, other objects of artistic, historical or archaeological significance, as well as scientific collections or important collections of books, archival materials or reproductions of the values mentioned above;

(b) buildings the main and actual purpose of which is to preserve or exhibit the movable cultural property referred to in paragraph (a), such as museums, large libraries, archives, and shelters intended for the preservation of movable cultural property in the event of armed conflict, referred to in paragraph (a);

(c) centres with a significant number of the cultural values referred to in points (a) and (b), the socalled "centres of concentration of cultural values" (Hague Convention 1954).

The analysis of the given normative acts gives grounds for the conclusion that things are cultural values. Instead, work is not a thing that clearly follows from the provisions of Part 1 of Art. 419 of the Civil Code of Ukraine, which states that the right of intellectual property and ownership of a thing does not depend on each other. Even when to take into account that works of fine art do not have the property of reproduction and their peculiarity lies in the coincidence of the material medium with a work in which it is embodied. In more detail, this principle is enshrined in Art. 12 of the Law of Ukraine "On Copyright and Related Rights", which contains a special reservation on material objects in which the original work of fine art or architecture is embodied.

In turn, not all works can be recognised as having cultural value, but only those that are included in the State Register of National Cultural Heritage, in accordance with paragraph 2 of the Regulations on the State Register of National Cultural Heritage, this register may include monuments of art, which means 
outstanding works of monumental, fine and decorative arts (Resolution of the Cabinet of Ministers of Ukraine No. 466-92-p 1992). It should be noted that the concept of "outstanding works" is legally vague, which is also evaluative. In addition, the formation of such a register includes administrative procedures that have nothing to do with creativity. Thus, if to apply the provisions of the above regulations in terms of qualifications of work as a result of creative activity, several conclusions can be drawn: first, not all creations of an author are works; secondly, the result of creative activity is only works that are recognised as cultural values, outstanding works; thirdly, in order for a creation to be recognised as a work, it must be entered in the state register. Instead, the provisions of Art. 8 of the Law of Ukraine "On Copyright and Related Rights" recognise as work the result of creative activity regardless of any formalities, both published and unpublished, both completed and incomplete, regardless of their purpose, genre, scope, purpose (education, information, advertising, propaganda, entertainment, etc.).

Even if to consider the preamble of the Law of Ukraine "On Professional Creative Workers and Creative Unions", which states that this Law determines the legal status of professional creative workers, establishes legal, social, economic and organisational principles of creative unions in the field of culture and art, a creative employee cannot always create a "cultural value" as a result of his professional creative activity. Creating cultural value is the exception rather than the rule. Therefore, the issue of adequate normative definition in the legislation of Ukraine of the term "creative activity" does not lose its relevance.

In turn, the case law has formulated its approaches to the definition of creative activity, creativity, originality and novelty, sometimes ambiguous, sometimes contradictory, sometimes unexpected. This situation can be explained by the existing confusion in the understanding of "creative work", "originality of works" and in general the criteria of protection of works, which introduces paragraph 18 of the Plenum of the Supreme Court of Ukraine "On the application by courts of the norms of legislation in cases of protection of copyright and related rights", which contains the following provision-presumption: "unless proven otherwise, the result of intellectual activity is considered to be created by creative work" (No. 5 from June 4, 2010). Thus, on the one hand, this paragraph of the Resolution states that copyright arises due to the fact of creation by intellectual, creative work of an author or co-authors of a work of science, literature and art. In this case, a work is considered created from the moment of its initial granting of any objective form, taking into account the essence of a work. On the other hand, when clarifying issues related to the protection of a part of a work, it is indicated that such objects are subject to protection as an object of copyright only if they are the result of the author's creative activity and are original.

The court's complete misunderstanding of the concepts of "creative activity" and "originality" can be found in the Resolution of the Supreme Economic Court of Ukraine in case No. 5023/9426/11. Thus, satisfying the cassation appeal in the motivating part, evaluating the decisions of previous courts, the court noted that the feature of work is originality, which determines the creative identity of an author, is a product of his creative thought and work and can be used independently (Resolution of the Supreme Commercial Court of Ukraine No. 5023/9426/11 2012). At the same time, when considering cases arising from disputed copyrights, unfortunately, the courts take into account not only the provisions of the law but also the established case law, which is reflected in the decisions of the Plenum of the Supreme Court. For example, the High Specialised Court of Ukraine, considering the case No. 755/12165/15-ts, and revoking the decision of the Court of Appeal of Kyiv, in the decision indicated that, based on the law, the court is obliged to find out the originality of the name in each case, because the assessment of originality is different in relation to works of literature, music, art, science, etc. (Resolution of the Board of Judges 2017), which is directly consistent with the provisions of Art. 9 of the Law of Ukraine "On Copyright and Related Rights".

In general, in practice, deciding whether one or another creation can be attributed to work, proceed from the opposite, bypassing the issue of creativity, despite the fact that in Art. 1 of the Law of Ukraine "On Copyright Protection and Related Rights", the author is a natural person who has created a work with his creative acting. Similar wording can be found in Art. 418 of the Civil Code of Ukraine (2003). According to Part 3 of Art. 8 of the Law of Ukraine "On Copyright Protection and Related Rights" (1993), legal protection of copyright "does not apply to any ideas, theories, principles, methods, procedures, processes, systems, methods, concepts, discoveries, even if they are expressed, described, explained, illustrated in work", and also things that cannot be works protected by copyright are in a list of objects enshrined in Art. 10 of the Law. Thus, if a work does not fall under the above list of objects, it can be recognised as a work protected 
by copyright, as well as if it can be attributed to a variety of works in the field of science, literature and art, enshrined in Part 1 of Art. 8 of the Law.

This approach is not original and is used by European scientists (Pihlajarinne 2017; Knobl 2002), and case law, which is more inclined to the nature of an artist, who as a result of his independent intellectual work, although he does not create completely new or original work, such work receives legal protection. This allows to extend the legal protection of copyright to works that are the result of little creativity of an author when the intellectual work of an author is more like mechanical work or subject to certain rules or standards, but such works meet the needs of society (Yali 2020). At present, the issue of creativity, its criteria and level (share) in the creation of copyright objects do not lose polemical urgency not only among lawyers but also representatives of other branches of science, such as art critics.

The approach enshrined in Directive 2001/29/EC of the European Parliament and of the Council of May 22, 2001 , on the harmonisation of certain aspects of copyright and related rights in the information society, according to which creativity is considered an activity, appears to be productive (paragraph 11). This provision of this Directive is taken into account in the national legislation of the EU member states when defining the criteria for the protection of copyright objects, although in general these criteria are defined differently in different countries. Thus, the legislation of Spain contains a set of requirements for work as an object of copyright, which allows to define it as an independent, original work created as a result of human creativity (Dreyer, Kotthoff and Meckel 2004). According to German legal doctrine, the conceptual approaches of which are based on legal provisions, a work is considered an intangible result of personal creative activity (Dreyer 2004 et al.; Dreier and Schulze 2004; Ren 2013; Szczepańska 2004). French copyright law does not contain a list of works that are protected as objects of copyright, but contains a list of criteria for the protection of works, which include the following: work must be the result of independent creative activity of an author; be characterised by originality, i.e. reflect the unique author's style; must be expressed in an objective form (written, oral, three-dimensional, be expressed in the form of video or audio). In the event of a dispute, the French courts must evaluate a work because all these criteria are present at the same time. For example, the Court of Cassation in the case of Societe Babolat Maillot Witt Pachot of 07.03.1986, assessing the creative contribution of the authors, noted that they demonstrated individual efforts that go beyond simple automatic and ordinary logic, and the result of such efforts was the materialisation of a work (Cour de cassation 1986). Summarising the above, it can be concluded that the legislator of the EU member states considers creativity as an activity that acts as an independent criterion for the protection of work while indicating that the result of such activity should be an original, independent, objectively expressed work.

In the United Kingdom, the criterion for granting legal protection to works is originality, and originality is seen as the author's efforts to create a work, skills used or intellectual effort. In each case, the originality of work is assessed separately through the author's connection with a work created by him (Bentley and Sherman 2004). At the same time, Art. 104 (5) (a) of the Copyright, Industrial Designs and Patents Act 1988 formulates a rather interesting presumption: if an author dies or if his identity cannot be established by reasonable effort, his work is considered to be original until evidence to the contrary (Copyright, Designs and Patents Act 1988; Horton 2019).

Even more ambiguous is the solution to the issue of granting legal protection to works that are characterised by an unstable form of expression, in terms of assessing their compliance with the criteria of protection. For example, the make-up of the face of the British musician Adam Anta has not recognised work by the British court in the case of Merchandising Corp of America v Harpbond Ltd (1983) FSR 32 as it cannot be equated with works of art on the grounds that the face cannot be considered superficial. At the same time, the court in the case Abraham Moon and Sons $v$ Thornber (2012) EWPCC 37 recognised as the copyright a drawing on a woollen plaid, on the grounds that the image had previously been drawn on paper.

In the United States, Art. 102 (a) of the Copyright Act (1976) stipulates that legal protection is granted to original works that have received their objective expression. In turn, the legal protection of copyright is not provided to unrecorded in writing or otherwise choreographic works, not recorded in writing or otherwise improvised speeches or performances; headings, names, short phrases and slogans; popular symbols or patterns; simple variations of printed patterns, inscriptions or colours; simple lists of ingredients or contents (Copyright Law of the USA 1976). Also, this provision of the Law provides an exclusive list of copyright objects that are provided with 
legal protection. However, case law allows for exceptions and additions to the provision of legal protection to works that are not included in the list, if such works meet the criteria of protection: originality and objectification. An example is the case of the Eastern American Trio Products v. Tang Electronic Corp. The court, after examining the level of originality of the disputed objects (photographs and their computer processing) in its decision concluded that any photograph could receive legal protection by copyright if the complexity of its production exceeds the complexity of scanning (Dobson 2009).

In contrast to the case-law of the United Kingdom, the courts of the United States in the issue of the legal protection of copyright stage make-up took the opposite position. Thus, the court recognised as the object of copyright the stage make-up applied by the authors of the famous Broadway musical "Cats", despite the fact that the actors constantly changed it during the performance, but applied in the same way (Carell v. Shubert Organization 2000). A similar decision was made in the case of Paramount Pictures Corp. v. Axanar Prods., Inc., by extending copyright protection to stage make-up used by actors in the Star Trek series (Paramount Pictures Corp. v. Axanar Prods. 2017).

An analysis of the case-law of the United Kingdom and the United States leads to the conclusion that courts in matters of extension of legal protection to works characterised by instability of form, and thus recognition of their works, do not take into account creative activity and originality as criteria for their protection. Judges, considering such cases, try to find qualitatively stable elements that are inherent in works with an unstable form of expression. In the United Kingdom, the court considers the medium on which work is recorded to be such a stable element, and in the United States, the method of creating a work. At the same time, unlike the courts, the institutions that register copyright objects take a completely different position, for example, the stage make-up of the members of the American band KISS, after they were denied registration as a copyright object, was registered as a trademark, on the grounds that it is more recognisable than the band members themselves.

Based on the above, it can be concluded that international law, national law, the case-law of different countries usually define the work as the result of intellectual creativity, and only then the criteria of protection can be distinguished that characterise the internal and external components of a work, such as originality, novelty, independence. At the same time, there are no provisions in the regulations that would answer the question of what kind of activity can be considered creative. Given that the implementation of creative activities is an inalienable human right, and the doctrine of copyright is the concept according to which a work is the embodiment of the author's idea, continuation and expression of his personality, throughout the life of the author remains inseparable, and the author's right to work is his natural right, it is possible to define creative activity as a spiritualpractical (internal-external) active human action. In this case, the first, internal, spiritual is carried out in the human mind, and external, practical - is associated with the embodiment of ideas and plans in specific content and form. At the same time, in order to realise his plans, an author can spend a lot of effort and time, engaged in technical work, for example, to find relevant material, to accumulate information.

Based on the analysis of special literature on creative activity (Ham 2012; Ermolaeva-Tomina 2005; Sergeev 2000; Druzhinin 2002; Danchay-Ool 2018), it can be stated that in psychology creative activity is considered through the prism of human intelligence, the separation of stages of the creation of a work from the origin of the idea in consciousness to its materialisation, in law - the emphasis shifts to the result creative activity, in art history - attention is focused on a personality of an author and his environment, cultural and social environment, which influenced the formation of his personality. Each of these sciences studies creativity, based on the subject of research, which is inherent in it with the use of appropriate scientific tools. At first glance, it may seem that there is no connection between these approaches to understanding creativity, but this is not the case. Creative activity is a purposeful activity, the result of which is usually predictable. The idea of creating a work, from which the creative process begins, is not the subject of legal science and is not subject to legal protection, but until then it will not be presented in a form that allows it to be perceived not only by an author but also by others. At the same time, a person who came up with the idea of creating a work, who gave this idea a form through which it can be perceived by a human using his feelings, from the point of view of law is its author, and from that moment there is not only psychological but also a legal connection between author and his creation. 
The further gradual transformation of an idea into a completed work is characterised not only by certain psychological processes and the corresponding psychological state of an artist, but it also reflects the inner world of an author, which is embodied in work due to the author's style, creating mood in the reader (in literature work), the use of controversy, the use of special terms, verbal turns adopted in certain fields of science (when creating works in the field of science), the use of appropriate techniques, the author's manner in creating works of fine art. At the same time, each stage of transformation of an idea into work is characterised by a certain result, which, having a material form of expression, is the object of legal protection and defence, as copyright protects both completed and unfinished work. The characters and the original title of a work may also be subject to legal protection. Thus, these approaches to the study and definition of the essence of creativity complement each other, provide an opportunity to learn all the depth and diversity of creative activity. At the same time, the author's creative contribution to the created work may be different.

If to turn to international legal acts, first of all, the Bern Convention "On the Protection of Literary and Artistic Works" (1886), in Part 1 of Art. 2 which stipulates that "the term 'Literary and artistic works' covers all works in the field of literature, science and art, in whatever way and in whatever form they are expressed...". Based on the above, it can be concluded that an artist is not limited to either the way or the form of expression of his creative idea. However, such a conclusion would be erroneous, because Part 2 of Art. 2 of this act provides that "under the laws of the Union the right to determine that literary and artistic works or any of their certain types are not subject to protection unless they are enshrined in one form or another material form reserves." That is, a work of art can receive its legal protection by copyright if it is enshrined in any material form, and therefore an artist is free of his artistic ideas, creative ideas, but he must implement them embodied in material form.

In a more generalised form, the provisions of the Berne Convention for the Protection of Literary and Artistic Works were enshrined in Part 2 of Art. 9 of the Agreement on Trade-Related Aspects of Intellectual Property Rights 1994: copyright protection extends to objectively expressed creative results, but not to ideas, processes, methods of work or mathematical concepts as such (Trade-Related Aspects of Intellectual Property Rights 1994). A similar wording with an indication of the form of expression of a work is contained in Art. 2 of the World Intellectual Property Organisation Treaty "On Copyright" (1996). World Copyright Convention in Art. 1 indicates the form of expression of works through their belonging to different types of arts and genres protected by copyright, namely: "works of writing, music, drama and cinema, works of painting, graphics and sculpture" (1952).

If to turn to the legislation of Ukraine in the field of copyright, then there is a conflict of its individual rules. Thus, the legislator in Part 2 of Art. 433 of the Civil Code of Ukraine almost verbatim repeated the provisions of Part 1 of Art. 2 of the Berne Convention "For the Protection of Literary and Artistic Works", stating that "works are subject to copyright without any formalities and regardless of their completion, purpose, value, etc., as well as the manner or form of their expression" (The Civil Code of Ukraine 2003). Instead, the Law of Ukraine "On Copyright Protection and Related Rights" in Part 2, 3 Article 8 considered both provisions of Part 1 of Art. 2 and Part 2 of Art. 2 of the Berne Convention for the Protection of Literary and Artistic Works, stipulating that all works, both published and unpublished, both completed and incomplete, are subject to protection, regardless of their purpose, genre, scope, purpose (education, information, advertising, propaganda, entertainment, etc.). Legal protection applies only to the form of expression of work and does not apply to any ideas, theories, principles, methods, procedures, processes, systems, methods, concepts, discoveries, even if they are expressed, described, explained, illustrated in work. Based on the above provisions of both the international legal act and the legislation of Ukraine, there is a necessity to clarify the question: should a work receive an objective form of expression or should it be recorded on a tangible medium to obtain legal protection by copyright?

\section{THE CONCEPT OF THE OBJECTIVE FORM OF EXPRESSION OF WORKS OF ART}

The objective form of expression of works of art will be the external expression of creative ideas, ideas of an artist, which in turn will allow work to be perceived by a person through the senses. That is, as V. Ionas rightly noted, the result of creativity can become the object of copyright only if it left the mental world of an author and took an objective form accessible to human perception (Ionas 1963). The objective form of expression depends on the manner in which a work is expressed, and not every form of expression of a work 
is sufficient to give it legal protection. An objective form of expression of work will be, for example, language, which makes a work accessible to listeners and perceived by the hearing organs. The way of expressing a work will be oral speech; the objective form of expression of a work, in this case, will be oral. It can be assumed that work during the oral presentation to the audience was recorded on a tangible medium, which led to a change in its objective form. The situation may be the opposite: a work was recorded on a tangible medium and had, for example, a written form of expression, but in the process of bringing it to the audience changed both the form of expression - from written to oral, and the content when the audience was brought not original text but its improvisation (translation of a work) without infringing the copyright of an author.

The question arises: in any case, work will be able to receive copyright protection? To answer this question, it is necessary to refer to the provisions of the Law of Ukraine "On Copyright and Related Rights". If to proceed from the provisions of Art. 8 of this Law, the answer should be yes in all cases, because the Law does not specify the form of expression of a work, meaning any form. At the same time, based on the provisions of the legislation - Art. 419 of the Civil Code of Ukraine and Art. 12 of the Law of Ukraine "On Copyright and Related Rights" the objective form of expression of works of art must be fixed on the material medium, which embodies a work belonging to the objects of the material world. Although the law does not directly require work to be affixed to a tangible medium in order to obtain legal protection, the copyright doctrine links the legal protection of work directly to the fixation of work on a tangible medium, effectively identifying it with an objective form of expression. And in this case, a work expressed orally and not recorded on a tangible medium, will not be able to acquire copyright protection. On the other hand, such a problem does not arise with regard to works of fine art. However, in order to eliminate this contradiction, it is necessary to make changes in the legislation, recognising as an objective form only that which is recorded on the material medium in which a work is embodied, as a condition for granting legal work protection.

An analysis of the international legal act and legislation of Ukraine in the field of copyright allows stating that works created by sand on glass, dirt on cars, snowshoes on snow, spices on coffee foam, etc. meet the requirements of copyright protection. Hands, brushes, sticks, rags, snowshoes and other objects of the material world used by artists are the means of reproducing creative ideas and plans. However, the material used by artists (sand, dirt, snow, foam, spices, cosmetics, make-up, etc.) is not by nature stable, unlike such common materials as paper, canvas, plaster, wood and art mean such as paints, pencils, pastels, inks, charcoal, stone, plaster, metal. The way of expression is drawing, and the form of expression of a work is a drawing. Ways of creation of a work of fine art can be modelling, carving, casting, forging, minting, etc., and the form of expression - sculpture. Material carrier in which the embodied work may coincide with the material used by the artist in creating the drawing, sculpture, for example, sand, when the drawing is created on the sand, and a sculpture of sand; snow drawings on snow, sculpture of ice, snow; foam drawing on the foam of coffee; stone - a sculpture in the form of relief on a stone. At the same time, the material carrier in which the embodied work may not coincide with the material: cosmetics, make-up drawings on the human body, dirt - a drawing on a car. The material carrier on which a work is embodied may be characterised by instability, and may also be stable.

The instability of the form in which the work is embodied was the reason for the authors' refusal to provide legal protection for their works. In this context, the case law on the extension of copyright to perfumes, which are also characterised by instability, is illustrative. For example, back in 1993, the District Court of Amsterdam (Netherlands) heard the case Lancôme vs Kecofa, the subject of which was a violation of copyright infringement of perfume "Tresor". Despite the fact that the claims of the French cosmetics company "Lancôme Parfums Et Beauté et Cie S.N.C." was not satisfied by the court because the scents of the perfumes of these firms were so different that they could not be confused, the court ruled that perfumes could be protected by copyright on the grounds that Dutch copyright law did not contain an exclusive list of objects, which may be granted copyright protection. At the same time, if the perfume meets the criteria of protection (an objective form of expression and the result of creative activity), it can be the subject of copyright. In this case, the court, deciding the case of copyright infringement, resorted to the argument, which is usually typical when considering cases of infringement of trademark rights, and dismissed the claim. Instead, in 2000 Lancôme again filed a lawsuit against Kecofa, and in 2006 the Dutch Supreme Court upheld the appellate court's position in upholding 
Lancôme's claims for copyright protection, but for protection of infringed rights of a sign for goods and services - refused, on the grounds that the aromas of two different companies cannot be confused. It should be noted that the subject matter of the dispute was the copyright infringement on the perfume as an object of copyright and not their recipe or combination of components (Koelman 2006).

A similar case was heard in 2007 by the French Supreme Court in the case L'Oreal $v$ Kecofa for infringement of the copyright of perfumes Trésor, Miracle, Anaïs-Anaïs and Noa, however, in contrast to Dutch judges, the French ruled that perfumes do not belong to the objects of copyright (Barista 2010). The final point on the possibility of copyright protection of flavourings in 2018 was made by the European Court of Justice, which in the case of Levola Hengelo BV v Smilde Foods BV stated that flavourings could not be attributed to copyright objects, as it may lead to legal uncertainty. Also in the motivating part of the decision, the court referred to its decision in the case Ralf Sieckmann C-273/00 on the legal protection of flavoured trademark, which provided an interpretation of the inexhaustibility of the list of protected designations in Art. 2 of Directive 89/104/EEC of 21.12.1988 "On the approximation of the laws of the Member States relating to trademarks as such, which includes olfactory designations". Summing up the analysis of this Directive, the court concluded that the presentation of the fragrance in the form of a chemical formula, verbal description and/or sample does not meet the criteria for graphic representation (McCutcheon, Hengelo BV v Smilde Foods BV). At the same time, in 2015, Regulation 2015/2424 and EEC Directive 2015/2436 "On approximation of the laws of the participating countries on trademarks" introduced new provisions on the possibility of registration of nontraditional trademarks, including olfactory (Directive (EU) 2015/2436 2015).

Also, covering the issue of objective expression of a work, it should be noted that in the doctrine of copyright, it is associated with the accessibility of perception of work by others (Liptsik 2002). It is known that a person perceives the world around him through five main sense organs: ears (hearing); eyes (sight); skin (touch); nose (sense of smell); tongue (taste). Usually, works of fine art have a visual perception, such non-standard works as drawings on dirty glass, snow, sand; the face is no exception; the same applies to sculptures created from sand or ice.
In the doctrine of copyright, a new concept of protection of works has appeared, which is called "Works with an insignificant level of creativity" or "Works with a minor authorship" (Lutkova 2016; Kashanin 2010; Kopylov 2019; Tomarov 2018; Petrenko 2019; Tokareva 2019). Such works are not named, i.e. those that are not distinguished in regulations, both international and national. Scholars have singled out such works by analysing judicial practice and current trends in the development of art. Researchers include photographic works, computer programs and databases, maps and plans, catalogues, brochures and slogans, descriptions of travel schemes, decorative and applied works (furniture, lamps, fashionable clothes, etc.), technical diagrams and drawings, telephone directories and other similar assemblies, programs and pop music products. Such works include works that have an unstable form of expression, in particular, make-up (Lutkova 2016).

Researchers explain the existence of such works by the fact that some regulations, such as Council Directive 93/98/EEC on the unification of copyright and related rights of October 29, 1993, lay down the provision that if a work reflects intellectual creativity of an author, it must be considered original (genuine) (paragraph 17), in addition, this Directive establishes a gradation of protection periods "in order to establish a high level of protection" for certain works (paragraph 11) (Council Directive No. 93/98/EEC 1993). As for the countries of Anglo-Saxon law, scholars justify the existence of works with a low level of creativity by the fact that in Britain and the United States there is an approach according to which copyright exists by virtue of the fact that it is provided by law. In addition, the copyright law of these countries does not establish as criteria for protection originality or novelty of work but links them to the independent creative efforts of an author, his skill and experience, and work should not be a copy of another work (Kashanin 2009).

Until 1991, there were two doctrines in copyright law in the United States: the "sweat of the brow" doctrine and the "creative selection" doctrine. According to the first doctrine, a work receives legal protection if its author directs all his efforts, including mechanical work, to create a work on another concept - a work can receive legal protection if the author's efforts are independent and the work is creative (Schwantner and Sesitsky 2018). In 1991, in the United States, the Supreme Court in the case of Feist Publications, Inc. v. Rural Telephone Service Co. with his decision put an end to the disadvantages and advantages of one or 
another concept, pointing out that the author's efforts should be creative, thus taking the position of "creative selection" ("creative selection doctrine") (Feist Pubs. v. Rural Tel 1991; Allner 2013; Kortelainen 2015; Secker and Morrison 2015).

Works that are characterised by an unstable form of expression due to their capture by photography or filming can be presented to the general public by posting them on the Internet or notification in television programs. As a general rule, if an author wishes to obtain a protection document, and in the countries of the Anglo-Saxon legal system to register his work and obtain legal protection by copyright, he must submit to the Institution his work recorded on a tangible medium. When it comes to works with an unstable form of expression, the question arises as to what will be the object of copyright protection: a work recorded on the sand, dirt on a car, snow, face, coffee, etc., whether a work will be protected reproduced on film or electronic media (photos, videos)? The question also arises in the event of a dispute, which will be protected in court - the original work or a derivative?

When there is a need to register copyrights for works of fine art, it is not always possible to submit the original work to the Institution, and then reproductions on film, photographs or electronic media of images of such works are submitted. The only question left is whether the Institution recognises the works recorded in this way as meeting the criteria of protection of works. Regarding the protection of the rights to works with an unstable form of expression, the original work of fine art may not be submitted to the court in all cases. As for the question of what will be the object of protection, the primary or derivative work, it is seen that the rights to both primary and secondary (derivative) work will be protected equally. In this case, a derived work can serve as proof of the existence of an original work. At the same time, if an original work has been destroyed, only the derivative work will be protected, because the principle of copyright applies: there is no work, there is no protection (Gu, Han, Jiang et al. 2020; Zuo and Ding 2020; Arai 2011).

Reproduced works with an unstable form on the usual material media, thanks to the original approaches of authors to the embodiment, objectification of their creative ideas, attract the attention of the general public and become vulnerable to plagiarism. However, when plagiarism occurs, disputes are usually resolved without recourse to the courts. For example, in 2016, a dispute arose between Ukrainian make-up artist Vlada
Haggerty and Kylie Cosmetics. Kylie Cosmetics has twice copied make-up ideas from Vlada's Instagram page to advertise its Christmas holiday campaign, HolidayEdition by Kylie Cosmetics. The photos were too similar, which could not be explained by a simple coincidence: red lips with the effect of amber, gold manicure and gold paint on the fingers that close the eyes. The dispute was resolved due to the fact that Kylie posted a post on Instagram, where she admitted that it was Vlada's work that inspired her to create this photo for the HolidayEdition collection, indicated Vlada's authorship and paid compensation. The second case, when the make-up created by Vlada Haggerty "Lip Drop" ("flowing lips") became twice the object of plagiarism. In 2017, it was copied by Kylie Cosmetics, and in 2018 by Makeup For Ever and Louis Vuitton. The conflict was also resolved without going to court (Kylie Jenner 2017; Haggerty 2018).

Another question needs to be clarified: whether the unstable form of expression of works affects the scope of the rights of their artist and whether all the rights that usually belong to an author can be exercised by authors of works with unstable form. The content of the intellectual property rights of a particular subject is characterised by a set of its subjective rights and responsibilities. The first and undisputed owner of the object of intellectual property rights is its author. It is an author of a work who decides whether he managed to realise the idea, the creative idea, whether a work is ready for presentation and bringing it to the public. It is an author who decides whether to withdraw a work from the private sphere. For copyrighted works, different people may own the original work and a copy. The work can be owned not only by authors but also by persons who have acquired copyright property rights to the work.

In the case of works expressed in an unstable form, the actual possession of the work is not always possible. For example, an artist chose dirt on the car as the material for the embodiment of his creative idea, and the car is not the property of an artist. This may raise the question of whether the artist's actions painting on other people's cars - can be considered a violation of the property rights of its owner. Painting machines do not damage the machines themselves and do not affect their purpose, quality and cost. In other words, the painting of cars cannot be considered as actions that damage property (cars). At the same time, not all owners will like the drawings that will decorate their cars, which depends on both the drawings themselves and the perception of their 
owners, the level of their creative culture. There is a well-known case described in the literature when a priest perceived a picture of a naked figure in the style of medieval artists on his car as pornography and, of course, was outraged. On the other hand, is it possible to talk about making copies of such drawings? It seems that it is impossible to make copies. As in this case, it is impossible to talk about the author's possession of his drawing. There is a situation when the material carrier on which the work is embodied, belongs to another person, and therefore the actual possession of such a work is not for an author, or even for a person who acquired property rights, but for a person who had no idea about the artist's intentions to choose his property as a "canvas" (Chung and Ko 2012; Balganesh 2009).

Law of Ukraine "On Copyright and Related Rights" in Part 2 of Art. 12 contains warnings for owners of fine arts who are not their authors. In particular, the owners of a material object in which a work of fine art or architecture is embodied are not allowed to destroy this object without first offering it to an author of work at a price not exceeding the cost of materials spent on its creation. It is clear that this rule cannot be applied in case of creation on a car. Just as there is no reason to talk about the primary and derivative ownership of the object of copyright, because an owner of a car is not an author of a work and has not acquired property rights to the work. The exception is the painting of a car at the request of its owner with special paints that do not wash off with water (rain) when a picture acquires a stable form of expression.

Creating work with dirt on cars, snow, sand destroys the idea of the obligatory initial stay of work (actual possession) only by an author of a work, because the created work with dirt on cars or snowshoes on snow immediately becomes available for an indefinite circle. Moreover, the process of creating work can be observed by persons who are not members of his family or close circle, as a result of which the work immediately becomes available to the public. In essence, there is a public demonstration of both the process of creating a work and the work itself.

The right to use a work usually belongs to its author and his successors and means the use of the object of copyright in order to obtain useful qualities that characterise such an object that can meet human needs. Ways of using the work depend on the work itself. The law does not limit the form and manner of use of the work. An exhaustive list of ways to use the works is given in Part 3 of Art. 15 of the Law of Ukraine "On Copyright and Related Rights". If to transform the above ways of using works, then in relation to works with an unstable form of expression it is possible to talk only about the exclusive right of an author to make a public demonstration or display of a work in person or granting such a right to, say, a car owner under a contract between an author and with the consent of a car owner. It is difficult to imagine the possibility of exercising the exclusive right of an author to grant permission or prohibit the use of a work created by snowshoes on snow or sand. Property rights that characterise subjective copyright include work with an unstable form of expression, including the right to create a derivative work, such as a photograph of work or a video. In this case, the realisation of such a right is possible without the consent of an owner of a material object in which a work is embodied (Grimes, Jaeger and Lin 2008; Stadler 2007).

An author may exercise the authority to dispose of the object in which the work is embodied, i.e. to decide its further legal fate, but in a sufficiently "cut" form. This right is exercised by an owner through voluntary restriction or termination of his right. Property copyright is restricted by transferring it in whole or in part, for example, only within a certain way of use by others. Although this power is theoretically possible, its validity will be limited to the existence of an object itself. As for the termination of intellectual property rights to work with an unstable form of expression, it is inherently no different from a similar right to objects that have a habitual form of expression. An author can change his creation and thus terminate both personal, intangible and property rights to the original work, creating another on its basis.

The realisation of the right of access to the work and the right to follow in relation to objects with an unstable form of expression is also quite problematic. In the case of sculptures made of ice or sand, author of such works may have the right to actually own such copyright objects. The content of the right to dispose of such objects of copyright may be characterised by the exclusive rights of an author: not only the right of public display or demonstration but also the right to grant permission to use such works (organisation of exhibitions, competitions, etc.). At the same time, as in the case of drawings, paintings, the validity of these rights will be limited by the actual existence of such objects.

\section{CONCLUSIONS}

The nature of the form of expression of a work - its stability or instability does not affect the receipt by a 
work of legal protection. The main thing is the possibility of a perception of a work, regardless of its form by the human senses, i.e. the presence of objectification of the form. For objects with an unstable form of expression, the material medium in which a work is embodied often coincides with the material from which a work is made, and the material form of expression coincides with the material medium in which a work is embodied (for paintings and drawings). The means used by an author to create such works are different from the usual means used by an artist and are characterised by diversity and originality. Legal protection of works with an unstable form of expression is provided subject to the creative contribution of an author in their creation. If a work is the result of creative activity, is characterised by uniqueness and originality of external and internal form, it is recognised as an object of copyright protection.

Compared with the legal protection of works of fine art with an unstable form of expression with similar objects of a stable form of expression, the content of the subjective copyright of their author is limited to a certain list of powers, solely due to the shape of these objects and its properties. In this case, it is not so much about the degree of stability of form, but about the features of the material used and the objects of the material world, which can be used as a "canvas" to create them. For works of fine art, the author's legitimacy is limited by the right to public display, demonstration, transfer of property rights to use such works to others, the methods of which, in turn, are limited to the right to create derivative objects, the right to public display. The term of legal protection is limited by the existence of such objects, which is largely due to the characteristics of the material used (snow, ice, sand, coffee foam, dirt, etc.).

The copyright objects studied in this article are related to unnamed copyright objects. The practice of their legal protection in different countries has its own peculiarities, which is due to the existing approaches to understanding the protective criteria of works, and above all, the understanding of creativity, creative activity. Since the boundaries of creative activity are immeasurable, the formalisation of works with an unstable form of expression at the level of legislative definition of their list seems impractical. A separate consolidation at the level of general principles of the copyright of legal protection of objects with an unstable form of expression and definition of their legal regime is considered more expedient.

\section{REFERENCES}

Allner, Irmin. 2013. "Copyright and the Delivery of Library Services to Distance Learners", pp. 179-192. Internet reference support for distance learners, edited by Miller, William, Pellen, Rita M. New York: Routledge. https://doi.org/10.1300/J136v09n03 13

American Convention on Human Rights (Pact of San José). 1969 (http://www.cidh.org/Basicos/English/Basic3.American\%20C onvention.htm)

Arai, Yasuhiro. 2011. "Civil and Criminal Penalties for Copyright Infringement". Information Economics and Policy 23(3-4): 270-280.

https://doi.org/10.1016/j.infoecopol.2011.08.001

Balganesh, Shyamkrishna. 2009. "Foreseeability and Copyright Incentives". Harvard Law Review 122(6): 1571-1633.

Barista, Guest. 2010. Smelly Rights: Copyright in Perfume (https://www.patentbaristas.com/archives/2010/01/19/smellyrights-copyright-in-perfume/)

Basic Law of the Federal Republic of Germany. 1949 (https://www.1000dokumente.de/?c=dokument_de\&dokumen $\mathrm{t}=0014$ _gru\&l=ru\&object=translation)

Bentley, Lionel and Brad Sherman. 2004. Intellectual Property Law: Copyright. St. Petersburg: Nauka.

Berne Convention for the Protection of Literary and Artistic Works. 1886 (https://www.wipo.int/treaties/en/ip/berne/)

Birštonas, Ramūnas, Thomas Hoffmann, Aleksei Kelli and Vadim Mantrov. 2014. "Soviet Period Films in Today's Copyright Law: German and Baltic Experience". Trames 18(3): 199220. https://doi.org/10.3176/tr.2014.3.01

Carell v. Shubert Organization, Inc., 2000. (https://www.ravellaw. com/opinions/efc737a5e0ec85d6c6c608834dc920cd)

Chung, Myoung Beom and IIJu Ko. 2012. "Intelligent Copyright Protection System Using a Matching Video Retrieval Algorithm". Multimedia Tools and Applications 59(1): 383-401. https://doi.org/10.1007/s11042-011-0743-z

Colton, Charles Caleb. 2004. Lacon, or Many Things in Few Words: Addressed to Those Who Think. Whitefish: Kessinger Publishing, LLC.

Constitution of Spain. 1978_(http://www.congreso.es/portal/page/ portal/Congreso/Congreso/Hist_Normas/Norm/const_espa_t exto_ingles_0.pdf)

Constitution of the Italian Republic. 1947 (https://legalns.com/ download/books/cons/italy.pdf)

Constitution of the Portuguese Republic. 1976 (http://www.concourt. am/armenian/legal_resources/world_constitutions/constit/port ugal/portug-r.htm.)

Constitution of Ukraine. 1996 https://zakon.rada.gov.ua/laws/show/ 254\%D0\%BA/96-\%D0\%B2\%D1\%80\#Text.

Copyright Law of the United States of America. 1976 (https://www.copyright.gov/title17/)

Copyright, Designs and Patents Act. 1988 (https://www.legislation. gov.uk/ukpga/1988/48/section/104)

Council Directive No. 93/98/EEC. 1993 October. "On Harmonising the Term of Protection of Copyright and Certain Related Rights" (https://eur-lex.europa.eu/legal-content/EN/ALL/?uri= celex\%3A31993L0098)

Cour de cassation, Assemblée Plénière. 1986 (https://www.legifrance.gouv.fr/juri/id/JURITEXT0000070169 34/)

Customs Code of Ukraine. 2012 (https://zakon.rada.gov.ua/laws/ show/4495-17\#Text)

Dafoe, To. 2020. "Meet the Former Engineer Who Makes MindBlowing Land Art with Nothing but a Pair of Snow Shoes and Some Simple Math" (https://news.artnet.com/art-world/simonbeck-snow-artist-1753317) 
Danchay-Ool, Alexander. 2018. Dialectic Interpretation of the Creative Personality Phenomenon. St. Petersburg: Russian State Pedagogical University.

de Baranda, Yolanda Bergel Sainz. 2011. Sale of Works of Art: Civil Law Problems. Örebro: Örebro University.

De Miguel Asensio and Alberto Pedro. 2012. Intellectual Property and Private International Law: Comparative Perspectives. Oxford: Oxford University Press.

Directive (EU) 2015/2436 of the European Parliament and of the Council of December 16, 2015, to Approximate the Laws of the Member States Relating to Trade Marks. 2015 (https://eur-lex.europa.eu/legalcontent/EN/TXT/?uri=CELEX\%3A32015L2436)

Directive 2001/29 / EC of the European Parliament and of the Council of May 22, 2001, on the Harmonisation of Certain Aspects of Copyright and Related Rights in the Information Society. 2001 https://zakon.rada.gov.ua/laws/show/984_00501\#Text.

Dobson, Kevin. 2009. "The Originality of Photographs for Purposes of Copyright Law Before and after. Bridgeman Art Library, Ltd. v. Corel. Corp". Florida Coastal Law Review X:319: 4469.

Dreier, Thomas and Gernot Schulze. 2004. Urheberrechtsgesetz Kommentar. Munchen: Verlag C.H. Beck.

Dreyer, Gunda, Jost Kotthoff and Astrid Meckel. 2004. Heidelberger Kommentar zum Urheberrecht. Heidelberg: C.F. Muller Verlag.

Druzhinin, Vladimir. 2002. General Ability Psychology. St. Petersburg: Piter.

Ermolaeva-Tomina, Liudmila. 2005. Psychology of artistic creativity. Moscow: Kultura.

European Convention on Human Rights. 1950 (https://www.echr.coe. int/documents/convention_eng.pdf)

Feist Pubs., Inc. v. Rural Tel. Svc. Co., Inc. 1999 (https://supreme.justia.com/cases/federal/us/499/340/)

Fichte, Johann. 2006. "Beweis der Unrechtmäßigkeit des Büchernachdrucks. Ein Räsonnement und eine Parabel". Werke 1:1791-1794.

From Dirt to Paintings: Drawings on Dirty Cars by Rafael Veyisov. 2013 (https://kulturologia.ru/blogs/121013/19010/)

Hague Convention for the Protection of Cultural Property in the Event of Armed Conflict. 1954 (https://pax.unesco.org/la/ convention.asp?KO=13637\&language $=\mathrm{E}$.)

Ham, Abby. 2012. "KISS' Attorney, Raymond E. Scott on Trademarking the Make-up" (http://www.kissasylum.com/ news/2012/06/02/kiss-attorney-raymond-e-scotttrademarking-makeup/.)

Han, Pon, Amu Sui, Toi Jiang and Chiao Gu. 2020. "Copyright Certificate Storage and Trading System Based on Blockchain", pp. 611-615. Proceedings of 2020 IEEE International Conference on Advances in Electrical Engineering and Computer Applications, AEECA 2020, Dalian: IAAST.

https://doi.org/10.1109/AEECA49918.2020.9213631

Harbin Ice Sculpture Festival. 2020 (https://www.tourister.ru/world/ asia/china/city/harbin/parades/35229)

Horton, Audrey. 2019. "Copyright: Infringement of Artistic Works and Fixation" (https://www.twobirds.com/en/news/articles/ 2019/global/copyright-infringement-of-artistic-works-andfixation)

International Covenant on Civil and Political Rights. 1966 (https://zakon.rada.gov.ua/laws/show/995_043\#Text)

lonas, Vladimir. 1963. Creativity Criterion in Copyright and Judicial Practice. Moscow: Yuridicheskaya Literatura.

Jaeger, Paul, Julia Lin and Justin Grimes. 2008. "Cloud Computing and Information Policy: Computing in a Policy Cloud?".
Journal of Information, Technology and Politics 5(3): 269283.

https://doi.org/10.1080/19331680802425479

Jani McCutcheon. "Levola Hengelo BV v Smilde Foods BV: The Hard Work of Defining a Copyright Work". Modern Law Review 82(5): 936-950.

https://doi.org/10.1111/1468-2230.12463

Kashanin, Andrey. 2007. "Creative Character as a Condition for the Protectability of a Work in Russian and Foreign Copyright". Bulletin of Civil Law 2: 75-119.

Kashanin, Andrey. 2009. "Minimum Standards for the Protection of Copyright Objects (Comparative Analysis)". New Justice. Case History Journal 3(4): 56-66.

Kashanin, Andrey. 2010. "Minimum Level of Creativity for Works in French Copyright". Right. Journal of the Higher School of Economics 1: 114-124.

Kashanin, Andrey. 2010. "Signs of Novelty and Originality of a Work in Copyright". Legislation and Economics 8: 39-50.

Kelsen, Hans. 1949. "Hundredth Birthday of Josef Kohler". American Journal of International Law 43(2): 346-347. https://doi.org/10.1017/S0002930000092149

Khokhlov, Vladimir. 2008. Copyright: Legislation, Theory, Practice. Moscow: Gorodets.

Knobl, Perrie. 2002. Die "kleine Münze" im System des Immaterialguter- und Wettbewerbsrechts". In Eine rechtsverglei-chende Analyse des deutschen, schweizerischen, franzosischen und US-amerikanischen Rechts. Hamburg: Verlag Dr. Kovac.

Koelman, Kasper. 2006. "Copyright in the Courts: Perfume as Artistic Expression" (https://www.wipo.int/wipo_magazine/en/2006/ 05/article 0001.html)

Kopylov, Alexey. 2019. "The Main Characteristics of the Work as an Object of Copyright". Matters of Russian and International Law 9: 106-112.

Kortelainen, Terttu. 2015. "Copyright Literacy in Finnish libraries, Archives and Museums". Communications in Computer and Information Science 552: 202-209. https://doi.org/10.1007/978-3-319-28197-1_21

Kylie Jenner Admitted That She Plagiarised the Work of a Ukrainian Makeup Artist. 2017 (https://elle.ua/ludi/novosty/onapriznalas-kayli-dzhenner-podtverdila-vorovstvo-chuzhihrabot/)

Law of Ukraine No. 1068-XIV 1999, September. "On Export, Import and Return of Cultural Property". (https://zakon.rada.gov.ua/ laws/show/1068-14\#Text)

Law of Ukraine No. 3792-XII 1993. "On Copyright and Related Rights" (https://zakon.rada.gov.ua/laws/show/3792-12\#Text)

Law of Ukraine No. 554/97-VR "On Professional Creative Workers and Creative Unions". 1997, October (https://zakon.rada.gov. ua/laws/show/554/97-\%D0\%B2\%D1\%80\#Text)

Lipstick, Donna. 2002. Copyright and Related Rights. Moscow: Ladomir; UNESCO Publishing.

Lutkova, Olha. 2016. "The Problem of Protectability of Works with an Insignificant Level of Creativity and Repeated Works in the Copyright of the Foreign States and the Russian Federation" (https://wiselawyer.ru/poleznoe/88993-problemaokhranosposobnosti-proizvedenij-neznachitelnym-urovnemtvorchestva-povtornykh)

Matveev, Alexander. 2015. Intellectual Rights to Works of Science, Literature and Art. Perm: Perm State National Research University.

Morgunova, Elena. 2008. Copyright. Moscow: Norma.

Paramount Pictures Corp. v. Axanar Prods., Inc. 2017 (https://www.copyright.gov/fair-use/summaries/paramountpictures-axanar-productions-jan-3-2017.pdf) 
Petrenko, Ivan. 2019. "Legal Protection of Atypical Works in Ukraine and Other Countries". Theory and Practice of Intellectual Property 4: 5-14. https://doi.org/10.33731/42019.175707

Pihlajarinne, Tiana. 2017. "Should We Bury the Concept of Reproduction - Towards Principle-Based Assessment in Copyright Law?". IIC International Review of Intellectual Property and Competition Law 48(8): 953-976. https://doi.org/10.1007/s40319-017-0654-2

Rachum-Twaig, Omri. 2017. "Recreating Copyright: the Cognitive Process of Creation and Copyright Law". Fordham Intellectual Property. Media and Entertainment Law Journal 27(2): article number 3.

Ren, Xan-Gon. 2013. "The Research of Legal Remedies for Network Copyright Infringement”, pp. 1515-1517. In: Proceedings of the 2013 3rd International Conference on Intelligent System Design and Engineering Applications, ISDEA 2013. Piscataway: IEEE

https://doi.org/10.1109/ISDEA.2012.363

Resolution of the Board of Judges of the Judicial Chamber for Civil Cases of the High Specialized Court of Ukraine for Civil and Criminal Cases in Case No. 755/12165/15-ts. 2017 (http://reyestr.court.gov.ua/Review/65110735)

Resolution of the Cabinet of Ministers of Ukraine No. 466-92-p 1992. "On Approval of the Regulations on the State Register of National Cultural Heritage" (https://zakon.rada.gov.ua/ laws/show/466-92-\%D0\%BF\#Text)

Resolution of the Plenum of the Supreme Court of Ukraine No. v0005700-10. 2010. "On the Application by Courts of the Norms of Legislation in Cases of Protection of Copyright and Related Rights" (https://zakon.rada.gov.ua/laws/show/ v0005700-10\#Text)

Resolution of the Supreme Commercial Court of Ukraine in the case No. 5023/9426/11. 2012 (http://reyestr.court.gov.ua/Review/ 24303321)

Sand Sculptures: The Dust of Time. 2020 (https://veryimportantlot. com/ru/news/obchestvo-i-lyudi/skulptury-iz-peska-pylvremeni)

Schwantner, Moas and Ehor Sesitsky. 2018. "Legal Protection of Works Generated by Artificial Intelligence Systems: The Experience of the EU, UK and USA". Journal of Kyiv University of Law 4: 210-2019.

Secker, Jane and Chris Morrison. 2015. "Copyright Literacy in the UK: Results from A Survey of Library and Information Professionals". Communications in Computer and Information Science 552: 191-201. https://doi.org/10.1007/978-3-319-28197-1 20
Sergeev, Alexander. 2000. Intellectual Property Law in the Russian Federation. Moscow: Prospekt.

Stadler, Sara. 2007. "Copyright as Trade Regulation". University of Pennsylvania Law Review 155(4): 899-960.

Sudarikov, Serhey. 2009. Copyright. Moscow: Prospect.

Szczepańska, Viktoria. 2004. "Digital Is Not Different - Copyright in Digital Environment”, pp. 395-403. IATUL Proceedings. Vol. 14 (New Series), Library Management in Changing Environment: Krakow: Krakow University of Technology.

The Civil Code of Ukraine. 2003 (https://zakon.rada.gov.ua/laws/ show/435-15\#Text.)

The Only Person in Yekaterinburg Who Enjoys the Slush: "A Dirty Car Is My Easel”. 2015 (https://www.e1.ru/news/spool/ news_id-53038911.html)

Tokareva, Viktoria. 2019. "Terms of Protection of Copyright Objects". Private and Public Law. 3:39-43. https://doi.org/10.32845/2663-5666.2019.3.9

Tomarov, Ivan. 2018. Videogram or Film: The Path to Reward (http://www.legalshift.com.ua/?p=1254)

Trade-Related Aspects of Intellectual Property Rights. Part I General Provisions and Basic Principles. 1994 (https://www.wto.org/english/docs_e/legal_e/27trips_03_e.htm)

Universal Copyright Convention. 1952 (http://www.unesco.org/new/ en/culture/themes/creativity/creativeindustries/copyright/universal-copyright-convention/)

Universal Declaration of Human Rights. 1948 (https://www.un.org/en/ universal-declaration-human-rights/)

Unusual Dirty Car Art by Scott Wade. 2019 (https://www.boredpanda com/dirty-car-art-by-scott-wade/?utm_source=google\&utm medium=organic\&utm_campaign=organic)

Vladamua (Vlada Haggerty). 2018 (https://www.instagram.com/ p/Bdshi9FB2T1/?utm_source=ig_embed)

World Intellectual Property Organization Copyright Treaty. 1996 (https://www.wipo.int/treaties/en/text.jsp?file_id=295166)

Yali, Cheng. 2020. "The Protection of Database Copyright in the Era of Big Data". Journal of Physics: Conference Series 1437(1): article number 012124. https://doi.org/10.1088/1742-6596/1437/1/012124

Zuo, Xo and Huiling Ding. 2020. "Research on Digital Copyright Infringement Based on Cloud Computing Environment", pp. 128-133. Proceedings of 2020 International Conference on Computer Engineering and Application, ICCEA. Guangzhou: Conference Publishing Services. https://doi.org/10.1109/ICCEA50009.2020.00034

Received on 01-01-2021

\section{DOI: https://doi.org/10.6000/1929-4409.2021.10.45}

(C) 2021 Myronenko et al.; Licensee Lifescience Global.

This is an open access article licensed under the terms of the Creative Commons Attribution Non-Commercial License (http://creativecommons.org/licenses/by-nc/3.0/) which permits unrestricted, non-commercial use, distribution and reproduction in any medium, provided the work is properly cited. 